\title{
The role of bio-detection dogs in the prevention and diagnosis of infectious diseases: A systematic review
}

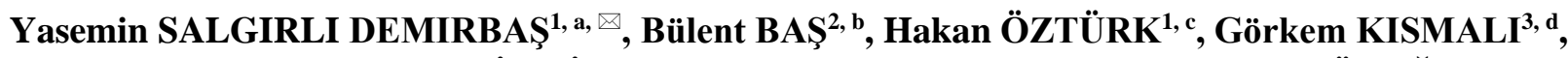 \\ Merve ALPAY ${ }^{4, \mathrm{e}}$, Hale SEÇILMIŞ CANBAY ${ }^{5, \mathrm{f}}$, Fatih EMEN ${ }^{5, \mathrm{~g}}$, Barış SAREYYÜPOĞLU ${ }^{2, \mathrm{~h}}$, \\ Aykut ÖZKUL, ${ }^{6, i}$
}

\footnotetext{
${ }^{1}$ Department of Physiology, Faculty of Veterinary Medicine, Ankara University, Ankara; ${ }^{2}$ Department of Microbiology, Faculty of Veterinary Medicine, Ankara University, Ankara; ${ }^{3}$ Department of Biochemsitry, Faculty of Veterinary Medicine, Ankara University, Ankara; ${ }^{4}$ Department of Biochemsitry, Faculty of Medicine, Düzce University, Düzce; ${ }^{5}$ Department of Chemistry, Faculty of Science, Burdur Mehmet Akif University, Burdur; ${ }^{6}$ Department of Virology, Faculty of Veterinary Medicine, Ankara University,

Ankara.

aORCID: 0000-0003-3869-3749; bORCID: 0000-0001-9992-8738; ' $O R C I D: 0000-0003-2913-2069$;

${ }^{\mathrm{d} O R C I D: 0000-0003-3414-4697 ;}$; ORCID: 0000-0002-8782-9561; f ORCID: 0000-0002-3783-8064;

gORCID: 0000-0002-4974-2940; ' ${ }^{O}$ ORCID: 0000-0002-2212-2610; iORCID: 0000-0001-5008-9443

Corresponding author: yaseminsalgirli@gmail.com

Received date: 01.12.2020 - Accepted date: 16.03.2021
}

\begin{abstract}
Infectious diseases have been lately considered as one of the most important global risks, which negatively impact not only the health but also the socioeconomic conditions of countries. Globalization influences the spread of infectious diseases as a result of increased travelling and interaction in humans. Thus, it is highly important to prevent and diagnose new infectious diseases by using accurate and quick diagnostic methods.

Bio-detection dogs have a great potential to accurately diagnose infectious disease as they have a great ability to sense diseasespecific volatile organic compounds (VOCs) originate from infectious agents and/or pathophysiological processes in the human body. The use of these dogs to detect infectious diseases has come to focus in particular after the recent global health crisis due to the SARSCoV-2 infection.

This review discusses the potential use of bio-detection dogs in the prevention and diagnosing of infectious diseases. Moreover, factors affecting the scent of the disease, e.g. VOCs, are tried to be highlighted.

Keywords: Bio-detection dogs, diagnosis, infectious disease, volatile organic compound (VOC).

\section{Enfeksiyöz hastalıkların önlenmesi ve teşhisinde biyo-dedektör köpeklerin rolü: Sistematik bir derleme}

Özet: Bulaşıcı hastalıklar, son zamanlarda sadece ülkelerin sağlığını değil, ekonomisini de olumsuz yönde etkileyen en önemli küresel risklerden biri olarak kabul edilmektedir. Küreselleşme, yeni insan seyahat modellerinin ve artan insan etkileşiminin bir sonucu olarak bulaşıcı hastalıkların yayılmasını etkilemektedir. Dolayısıyla yeni bulaşıcı hastalıkların doğru ve hızlı teşhis yöntemleri kullanılarak önlenmesi ve teşhis edilmesi büyük önem taşımaktadır.

Biyodedektör köpekler, insan vücudundaki (pato)fizyolojik süreçler sırasında oluşan hastalığa özgü uçucu organik bileşikleri (VOC'ler) ayırt etme konusunda büyük bir yeteneğe sahip oldukları için bulaşıcı hastalıkları doğru bir şekilde teşhis etmede önemli bir potansiyele sahiptir. Bu köpeklerin enfeksiyöz hastalıkları teşhis etmek için kullanılması özellikle SARS-CoV-2 enfeksiyonu nedeniyle yakın zamanda yaşanan küresel sağlık krizinden sonra araştırmaların odak noktası haline gelmiştir.

$\mathrm{Bu}$ derleme, bulaşıcı hastalıkların önlenmesi ve teşhisinde biyodedektör köpeklerinin potansiyel kullanımını tartışmaktadır. Ayrıca hastalık kokusunu etkileyen faktörler yani VOC'ler de aydınlatılmaya çalışılmıştır.

Anahtar sözcükler: Biyodedektör köpek, enfeksiyöz hastalık, teşhis, uçucu organic bileşikler.
\end{abstract}

\section{Introduction}

A virus called the Novel Coronavirus (2019-nCoV) or Severe Acute Respiratory Syndrome Corona Virus 2
(SARS-CoV-2) originating from the City of Wuhan in Hubei Province, China, has spread globally and affected more than 100 countries within a few weeks in 2020 . The 
World Health Organization (WHO) declared the SARSCoV-2 a global pandemic after the epidemic criteria have been reached in a short time $(12,45,53)$. Since the beginning of the recent SARS-CoV-2 outbreak, a great priority has been placed on the necessity of preparing health systems against the spread of this virus worldwide (12). Given high contagiousness of the virus and the significant role of asymptomatic individuals on the spread of the virus, the development of new strategies to detect the virus and to prevent the spread of the disease is particularly important $(13,48)$. Currently, real-time screening technologies are being used as the most common methods to control infectious disease in all over the world. These methods require several pre-analytical steps such as collection, appropriate storage and transportation of samples to a laboratory. Moreover, due to high cost, routine application of these methods brings a serious economic burden to the countries in case of any disease that is considered pandemic. Thus, it is of great importance to develop diagnostic methods that are sensitive, fast, accurate, economical and easily applicable to the field for public health as well as for border security management (3).

As seen in SARS-CoV-2 outbreak, new infectious diseases account for significant morbidity and mortality in humans. These diseases have been emerging in the global world due to several factors such as overpopulation in cities, increased international travel of people, and increased contact of humans with disease vectors and reservoirs in nature (63). According to the World Health Organization Report in 2007, spreading and emerging of infectious diseases are significantly faster since the 1970 's. Experts also state that viral infections such as Severe Acute Respiratory Syndrome Coronavirus (SARSCoV), H1N1 influenza, Middle East Respiratory Syndrome Coronavirus (MERS-CoV) and Severe Acute Respiratory Syndrome Corona Virus 2 (SARS-CoV-2) which all of them are life threatening globally (13) have emerged in last decades. Therefore, emerging infectious diseases are considered as serious threats to global public health and economy. One of the main aims of the global public health security is to take proactive and reactive measures to decrease the risks, which negatively affect the human health (64).

Bio-detection dogs have come to the fore lately to detect "asymptomatic" individuals having an infectious disease in many countries because of their high ability to diagnose the disease and, further of their ease of use in the field $(22,29)$. These dogs are specifically trained dogs using their sense of smell to diagnose infection-specific VOCs. Domestic dog (Canis familiaris) has a high developed olfactory system which can detect VOCs related to metabolic and infectious diseases in body fluids and breath. Although these specific VOCs can be identified by methods such as gas chromatography-mass spectrometry (GC-MS), potential use of this method as a diagnostic tool is limited because it is time consuming, expensive and it requires qualified operators (42). It has been reported that dogs' exceptional sniffing performance is comparable to the current mass spectrometry-based laboratory applications and is capable of detecting compounds close to the femtomolar level $(33,62)$.

The focus of this review is to provide an overview of the current literature and future perspectives related to the use of bio-detection dogs in diagnosing infectious disease including SARS-CoV-2 infection.

\section{Olfactory System of Dogs}

A dog's sense of smell is 10,000 to 100,000 times more accurate than a human's smell because of their highly developed olfactory system which is specialized to detect messenger chemicals, e.g. pheromones for communication and evaluation of the environment $(9,62)$. The olfaction is involved in a complex chemical network such as perception of an odor which is mediated by olfactory receptors (OR) in the nasal cavity and the identification process through which the chemical signal is converted into an electric signal and transmitted to the brain. The olfactory system of dogs comprises of two systems which are the main olfactory system and the accessory system. The main olfactory system includes the olfactory mucosa, which contains the respiratory epithelium and the olfactory epithelium with olfactory receptors. These two epithelia cover the nasal turbinates within the nostrils. Surface of the mucosa is increased by three turbinates located in each nostril (44). The major cells located in the olfactory epithelium are olfactory bipolar neurons $(4,87)$. The dentrites of these neurons end in cilia, which help increasing interaction between odorant molecules and olfactory receptors (ORs) located on the cilial membrane (87). The olfactory nerve including the axon groups of the olfactory neuron transmits the signal to the olfactory bulb. The olfactory bulb is a relay station, e.g. synaptic area between primary and secondary olfactory neurons within the glomeruli. The perception of odors depends on the glomeruli map as each odor may activate a different glomerular pattern (19).

The accessory system comprises of the vomeronasal organ (VNO) and the accessory olfactory bulb. It was previously believed that the main olfactory system and accessory system are anatomically and functionally different from each other. The accessory system was tought to be responsible for numerous neuroendocrine and behavioral responses by responding to pheromones, while the main olfactory epithelium was responsible for conscious scenting by responding the volatile chemicals $(38,67)$. However, it is now known that both systems can respond volatile compounds simultaneously with different selectivity (67). 
Many studies show that dogs have high packing density of neurons (44), and an increased number of functional genes against pseudogenes in the olfactory receptor gene family (49). Compared to humans, dogs have $\sim 3$ times more genes encoding olfactory receptors, a 30 times larger extension of the olfactory epithelium, approximately 50 times more olfactory receptors, and 3 times larger bulbus olfactorius (37). Thus, VOC biomarkers are within the detection range of the canine olfactory system. In addition to all these features, the nasal cavity in dogs contains hundreds of millions of sensory neurons in the nasal epithelium. Although the acuity of smell in dogs is associated with the large sensory organ size and receptor gene repertoire, the fluid dynamics of the transmission during sniffing are also of great importance in perception of smell (15)

\section{History of Bio-detection Dogs}

Detection dogs have long been used for hunting purposes, solving criminal cases, finding landmines and searching for victims of natural disasters successfully. Recently, a new field for detection dogs has emerged, in which they are trained to identify medical diseases. These dogs are called bio-detection dogs and trained to use their sense of smell to detect a wide variety of substances, mostly volatile organic compounds (VOCs), which are exceptionally or specially produced in people with metabolic or infectious disease.

The first publication regarding the detection dog in the medical field was a case report published in 1989 by Williams (65). According to this report, a Border Collie and Doberman Pinscher cross dog constantly sniffed a spot on the owner's leg for a long time. It was later found out that the spot where the dog was pointing was melanoma. The first studies on the use of trained dogs in cancer diagnosis were published in earlier 2000s. Willis et al. (66) reported that dogs were able to diagnose bladder cancers. Pickel et al. (43) later confirmed that dogs were successful in diagnosing melanoma. More importantly, in that study it was claimed that the further examination of a patient with negative initial pathology revealed melanoma after the dogs indicated this patient as positive. Another study conducted by McCulloch et al. (36) demonstrated that detection dogs showed high sensitivity and specificity in the diagnosis of lung and breast cancers from patients' breathing air. Horvarth et al. (25) further reported that dogs were successful not only in distinguishing between cancerous and normal tissue, but also in distinguishing non-cancerous pathological tissue (diseases that cause inflammation, necrosis or the emergence of metabolic products) from cancerous tissue. In another study conducted on ovarian cancers, it has been shown that dogs showed high success in the diagnosis of cancer from blood with $100 \%$ sensitivity and $95 \%$ specificity values (26).
Dogs were found to be able to diagnose early stages of colorectal cancers and can detect this type of cancer from respiratory air with $92 \%$ sensitivity and $99 \%$ specificity (55). Similarly, Malinois breed detections dogs responded correctly in 30 of 33 cases in the diagnosis of prostate cancer from dog urine with $91 \%$ sensitivity and specificity (14). Ehmann et al. (17) reported that detection dogs were able to differentiate lung cancers from chronic obstructive pulmonary disease (COPD) by sniffing the breathing air. Furthermore, they also showed that smoking and nutrition did not negatively affect the diagnosis when using detection dogs. Today, cancer detection dogs are routinely trained and used to diagnose cancer in many countries. Nowadays, many centers of foundations have been established to train and use cancer detection dogs (32).

\section{What do bio-detection dogs smell?}

Hundreds of volatile organic compounds are released from the human body. As they reflect the metabolic state of the individual, body odor of individuals with any metabolic or infectious disease changes due to VOCs (52). Numerous studies have shown that VOCs can be specific to a specific pathogen or infection $(8,50)$. For instance, different VOC expression patterns were detected in primary human tracheobronchial cells infected or not infected with human rhinovirus (50). Similarly, VOCs produced by B lymphoblastoid cells following infection with three different viable influenza virus subtypes have been reported to be unique for each virus subtype (2). In a different study, VOCs associated with bacterial and viral growth were detected and it was revealed that VOCs can be used in the differentiation of these infections (1). Furthermore, it has been demonstrated that VOCs in the respiratory air change after the H1N1 vaccine (34). These studies show that unique VOC profiles can be associated with viral pathogens, which can be detected in patients.

Today, physical, biochemical and molecular biological methods are accepted as common routine methods used for medical monitoring and clinical diagnosis. In these analyzes, blood and urine are mostly used as samples. Diagnoses based on breath analysis are much less common. Compared to research on human fluids such as urine, feces, and blood sampling, analysis of breath is preferred as it is considered a non-invasive approach. The sample quantity is unlimited. The measurement and detection of volatile compounds in a gaseous matrix is much simpler than in a more complex biological matrix such as blood. Although analyzing and characterizing the breath sample and defining the diagnostic VOC model with statistical data allows to obtain strategic information for clinical diagnosis, it has not yet widely been used in clinical practice.

Breath analysis for VOC detection is now routinely performed for certain reasons as follows: 
- Diagnosis of Helicobacter pylori infection by monitoring the carbon dioxide level (21),

- Diagnosis of airway inflammatory conditions by monitoring the fractional exhaled nitric oxide (FeNO) level $(39,47)$,

- Ethanol and acetaldehyde concentrations in the blood alcohol test (11),

- Detection of acute and/or chronic diseases $(54,56)$.

Is the $\mathrm{VOC}$ in breath useful for bio-detection dog training? Changes in VOC profiles may arise from pathogens themselves, host-pathogen interactions, and host immune responses (16). Numerous experiments have been performed over recent years using breath gas analysis for the non-invasive identification of different diseases. (5). VOCs are assumed to be transferred from various organs to the lungs via blood and subsequently excreted by diffusion via the alveolar pulmonary membrane and exhalation by air (61). The majority of published reports have centered on VOC analysis from exhaled breath for establishing the etiologic diagnosis of respiratory infections $(31,40)$.

By sampling breath, feces, urine, blood, and tissue, detection dogs are capable of detecting cancer. In certain cases, in exhaled breath, which includes the lowest known volatile VOC levels, dogs were able to detect disease states (51). Besides the several advantages to use breath, there are still some limitations such as sample collection. Sonoda et al. (55) trained a dog using samples of exhaled breath to test patients with colon cancer. Breath samples were collected into a breath-sampling bag, sealed and stored in a refrigerator until dog training. The sensitivity and specificity of this dog in breath samples for cancer detection was 0.91 and 0.99 , respectively (55). A cylindrical polypropylene organic vapor testing tube was used in another study and showed that the cumulative sensitivity of canine scent detection of lung cancer using exhaled breath samples was 0.99 , with a precision of 0.99 (36).

Regardless of the sampling method, it can be said that the ability of dogs to recognize the smell of breath is quite high and unique. In view of the risks associated with the collection of breath samples in infectious diseases, the correct method should be chosen and these samples should be used in dog training. The selection of methods and materials to be used is very important for both biodetector dogs and public health.

\section{Detection of infectious disease by bio-detection dogs}

History showed that various pathogens such as bacteria, viruses and parasites can cause outbreaks, which may become a threat to human population. These pathogens include bacteria such as Bacillus anthracis, Francisella tularensis, Yersinia pestis, viruses such as
Variolavirus, filoviruses (Ebola), arenoviruses (Lassa), and influenza viruses as well as parasites such as Plasmodium falciparum (Malaria). Authorities outlined the critical importance of affordable, fast and reliable diagnostic methods to prevent spread of dangerous infectious agents as the outbreaks affect not only the health issues and economy but also they result in social disruption and panic in the human population (27).

Lately, bio-detection dogs have come to the focus of intense attention as these dogs have been reported to detect various kinds of infectious agents with a high sensitivity and specificity from body fluids, extracts and respiratory air of humans. These promising results revealed high potential for using bio-detection dogs in the diagnosis of infectious agents in populations and further in prevention of spread of infectious diseases. In this part, we will discuss the studies about the use of dogs in detection of various infectious diseases.

Bacterial Diseases: For the detection of bacterial diseases, dogs are expected to identify volatile metabolites, which are bacteria-specific fingerprints and produced during microbial replication (33). Two different training approaches have been conducted in the studies on the detection of bacterial infections by dogs. Accordingly, dogs were either trained to point the highest concentration or source of odor in an ambient air or they are trained to detect the compounds in the steam accumulating from the samples presented to the dog (58). After the training, detection dogs can perform rapid diagnosis of diseasecausing pathogens in ex-vivo clinical specimens of patients or in-vitro bacterial cultures.

Clostridium difficile Infections: Clostridium difficile is a Gram-positive bacterium that causes symptoms such as formation of gas in the digestive system, diarrhea and abdominal pain. If this situation is not noticed in the early period, more severe cases such as colitis and megacolon can be observed in the affected individuals and the rapid and easy transmission of the agent may also cause important hospital infections.

The first study showing that dog's developed olfactory system can be used in the diagnosis of an infectious disease agent was conducted by Bomers et. al. (6). In this study, researchers reported that a well-trained Beagle dog detected $C$. difficile in stool samples with $100 \%$ specificity and sensitivity. The dog also detected $C$. difficile-infected patients with a high predictive sensitivity $(83 \%)$ and specificity (98\%). The encouraging results obtained from the previous study motivated the researchers to test the diagnostic efficacy of the same detection dog during a $C$. difficile outbreak in a hospital in the Netherlands (7). In the following study, the same dog performed 651 scans of 371 patients during 9 hospital visits and was able to detect 12 of 14 cases with $86 \%$ sensitivity and $97 \%$ specificity. In this study, it has been 
shown that the detection dog can detect not only the current infection but also the clinical cases that are likely to occur in the near future (7).

Another group of researchers investigated whether a detection dog can detect environmental $C$. difficile reservoirs by smell. A dog was trained to detect odors released from pure culture and fecal samples found positive for $C$. difficile. The $\operatorname{dog}$ was successful in detecting agent-specific odors with high sensitivity $(100 \%)$ and specificity (97\%). As a result of this study, it was reported that since trained dogs can successfully detect $C$. difficile scent in environmental sources, this feature can be used to take necessary cleaning measures in the relevant health facility and they can be used successfully in infection control programs as well (10).

In a different study using detection dogs, it was reported that dogs were able to detect $C$. difficile strains containing the toxin gene in stool samples, but the interrater reliability was not high enough, suggesting that dogs have limited practical value in the point-of-care diagnosis of $C$. difficile infection and will never reach the efficacy of molecular tests that provide diagnosis with extremely high accuracy (57).

Methicilline Resistant Staphylococcus aureus (MRSA) Infections: Detection dogs were successfully used for identification of bacterial infections in medicine. By analyzing the differences in volatile organic compound (VOC) profiles, even antibiotic-resistant and susceptible strains of the same bacterial species can be distinguished from each other. In a study based on this feature, detection dogs were successful in distinguishing methicillinresistant Staphylococcus aureus strains, one of the most important hospital infection agents, not only from other Staphylococcus species, but also from methicillinsusceptible strains of the same species (30).

Urinary Tract Infections: Urinary tract infections (UTI) are among the most common hospital infections in hospitalized patients. Urinary system infections are caused by infectious bacteria such as Escherichia coli (responsible for $80 \%$ of UTIs), Staphylococcus aureus, Proteus spp., Enterococcus spp., Pseudomonas spp., Enterobacter spp., and Klebsiella spp. as well as fungal infections such as Candida spp.

In a study conducted by Maurer et al. (35), dogs were trained to distinguish culture positive urine samples from culture negative urine samples in cases of bacteriuria. Dogs have successfully detected the agent with a sensitivity of $99.6 \%$ and specificity of $91.5 \%$ in 250 samples containing $1 \times 10^{5} \mathrm{E}$. coli colonies per milliliter. Dilution of samples at $1 \%$ and $0.1 \%$ concentration did not alter the diagnostic accuracy. Moreover, diagnostic accuracy was achieved with $100 \%$ sensitivity and $93.9 \%$ specificity in 50 samples containing Enterococcus spp., $100 \%$ sensitivity and $95.1 \%$ specificity in 50 samples containing Klebsiella spp., and $100 \%$ sensitivity and $96.3 \%$ specificity in 50 samples containing S. aureus. These results revealed that dogs can be trained and used successfully for early and accurate diagnosis of bacteria that cause UTI.

Detection Dogs in Veterinary Medicine: Detection dogs have been used in Veterinary Medicine to diagnose cows with mastitis. Dogs were trained using specific bacterial cultures, artificially contaminated raw milk samples and field milk samples collected from cows with mastitis to detect Staphylococcus aureus that is a common pathogen isolated from clinical and subclinical mastitis samples. Their respective sensitivity and specificity were $91.3 \%$ and $97.9 \%$ in bacterial cultures, $83.8 \%$ and $98 \%$ in raw milk and $59 \%$ and $93.2 \%$ in samples obtained from cows with mastitis (18).

Parasitic Diseases: The studies on detection dogs to identify pathogens are not limited to the bacterial infections. In a recent study, dogs were reported to detect malaria from nylon socks of asymptomatic children with a greater sensitivity than the routine diagnostic methods. The results in asymptomatic malaria-infected and noninfected individuals were broadly in line with the WHO's criteria for the provision of rapid diagnostic tests, by which the test should be able to detect at least $75 \%$ of the parasite agent of Plasmodium falciparum samples (23). This study was one of the pioneer studies showing that dogs are able to detect infectious disease even in asymptomatic patients.

Viral Diseases: Viruses, like bacteria, are found in all living organisms, including humans, animals and plants. Since viruses rely on host cellular functions to propagate and replicate, they cause metabolic reprogramming in the cells (60). It was claimed that metabolic changes occurred in host cells because viral agents mirror metabolic changes seen in cancer cells (41, 60). These metabolic changes include upregulation of nutrient consumption, nucleotide and fatty acid synthesis as well as exhibiting the Warburg effect, e.g. increased glycolytic metabolism to support viral replication and rapid cell proliferation (41). Recent studies have reported various metabolic changes in the host cells induced by different viral agents such as adenovirus (59), human cytomegalovirus (68), influenza A Virus (46) and herpesvirus (20). Routinely used methods for identifying viral infections are limited and expensive or resourcedemanding conditions. Given dogs have the ability to detect VOCs caused by cancer and bacteria, they are considered as potential detectors which can detect metabolic changes caused by viruses in human body.

Dogs' ability to detect metabolic changes due to viral infections was demonstrated by different studies. In a study, dogs' ability to distinguish BVDV, BHV1 and BPIV3 infected kidney cell cultures were investigated. In 
this study, dogs detected bovine viral diarrhea virus (BVDV) with high diagnostic specificity $(95 \%)$ by smelling the infected cell cultures which suggest that dogs can be used as a realistic real-time mobile pathogen detection technology in diagnosing viral pathogens in cultured cell groups (3).

Recent studies on bio-detection dogs have mostly focused on SARS-Cov-2 infection. For example, Grandjean et al. (22) showed that dogs can diagnose SARS-CoV-2 by the odor of sweat released from axillary glands. Four out of eight dogs used in this study succeeded in detecting positive samples with a $100 \%$ accuracy. The success rates of other dogs were reported as $83 \%, 84 \%$, $90 \%$ and $94 \%$, respectively. Similarly, Jendrny et al. (28) reported that dogs were successful in the diagnosis of SARS-CoV-2 with $82.63 \%$ sensitivity and $96.35 \%$ specificity by sniffing saliva and trancho-bronchial secretions.

\section{Conclusion and Future Direction}

Studies on bio-detection dogs emphasized several advantages of using bio-detection dogs in detecting infectious disease. As these dogs are mobile, they are suitable for searching infectious both indoor and outdoor environments. They can be an important real-time and rapid diagnostic tool in areas such as airport, farm, slaughterhouse, etc. where diagnosis is critical. They can easily be trained for new scents and, thus for diagnosing new infections. Furthermore, the ability of dogs to recognize infectious diseases by smell may be evidence that special volatile compounds are produced in these infectious diseases, which allows the development of new laboratory diagnostic methods.

However, there are some limitations needed to be discussed in the use of bio-detection dogs. In addition to the risk of possible infection with the targeted pathogens, if biosecurity rules are violated, they may play a role in the transmission of the agent to the environment and people. Therefore, they should be tested regularly for possible infection with the investigated pathogen. It has been demonstrated that some drugs used in the treatment of dogs affect their sense of smell negatively. Thus, dogs on any medical treatment should exclude from detection work.

Detection dogs also have an important potential in the diagnosis of infectious diseases in veterinary medicine. Primarily, they can be used as a pre-diagnosis tool in herd screening for bacterial endometritis and mastitis infections seen in large animals. They can be used in the investigation of chronic and subclinical diseases such as paratuberculosis, which are difficult to diagnose in the early period. They can further be trained to investigate the presence of bacterial pathogens and mycotoxins in food and feed samples. Another issue that needs to be investigated is whether these dogs have the potential to recognize more than one factor at the same time (multiple diagnoses) for a particular clinical case.

As a conclusion, detection dogs are promising and rapid diagnostic tools in diagnosing infectious diseases in both human and veterinary medicine. However, for success in olfactory-based diagnosis, attention should be paid to factors such as using the correct dog, proficient trainer, correct sampling method, biosafety rules and appropriate training method.

\section{References}

1. Abd El Qader A, Lieberman D, Shemer AY, et al (2015): Volatile organic compounds generated by cultures of bacteria and viruses associated with respiratory infections. Biomed Chromatography, 29, 1783-1790.

2. Aksenov AA, Gojova A, Zhao W, et al (2012): Characterization of Volatile Organic Compounds in Human Leukocyte Antigen Heterologous Expression Systems: A Cell's "Chemical Odor Fingerprint. Chem Bio Chem, 13, 1053-1059.

3. Angle C, Waggoner LP, Ferrando A, et al (2016): Canine detection of the volatilome: a review of implications for pathogen and disease detection. Front Vet Sci, 3, 47.

4. Barrios AW, Núñez G, Quinteiro SP, et al (2014): Anatomy, histochemistry, and immunohistochemistry of the olfactory subsystems in mice. Front Neuroanat, 8, 63.

5. Bergmann A, Trefz P, Fischer S, et al (2015): In Vivo Volatile Organic Compound Signatures of Mycobacterium avium subsp. paratuberculosis. PLoS ONE, 10, e0123980.

6. Bomers MK, van Agtmael MA, Luik H, et al (2012): Using a dog's superior olfactory sensitivity to identify Clostridium difficile in stools and patients: proof of principle study. BMJ, 345, e7396.

7. Bomers MK, van Agtmael MA, Luik H, et al (2014): A detection dog to identify patients with Clostridium difficile infection during a hospital outbreak. J Infect, 69, 456-461.

8. Bos LDJ, Sterk PJ, Schultz MJ (2013): Volatile metabolites of pathogens: a systematic review. PLoS Pathog, 9, e1003311.

9. Brooks SW, Moore DR, Marzouk EB, et al (2015): Canine Olfaction and Electronic Nose Detection of Volatile Organic Compounds in the Detection of Cancer: A Review. Cancer Investigation, 33, 411-419.

10. Bryce E, Zurberg T, Zurberg M, et al (2017): Identifying environmental reservoirs of Clostridium difficile with a scent detection dog: preliminary evaluation. J Hosp Infect, 97, 140-145.

11. Buszewski B, Kesy M, Ligor T, et al (2007): Human exhaled air analytics: Biomarkers of diseases. Biomed Chromatogr, 21, 553-566.

12. Callaway E (2020): Time to use the p-word? Coronavirus enter dangerous new phase. Nature, 579, 12.

13. Cascella M, Rajnik M, Cuomo A, et al (2020): Features, evaluation and treatment coronavirus. (COVID-19), StatPearls.

14. Cornu JN, Cancel-Tassin G, Ondet V, et al (2011): Olfactory detection of prostate cancer by dogs sniffing 
urine: A step forward in early diagnosis. Eur Urol, 59, 197201.

15. Craven BA, Neuberger T, Paterson EG, et al (2007): Reconstruction and morphometric analysis of the nasal airway of the dog (Canis familiaris) and implications regarding olfactory airflow. Anat Rec, 290, 1325-1340.

16. Dummer J, Storer Swanney M, McEwan M, et al (2011): Analysis of biogenic volatile organic compounds in health and disease. Trends Anal Chem, 30, 960-967.

17. Ehmann R, Boedeker E, Friedrich U, et al (2012): Canine scent detection in the diagnosis of lung cancer: Revisiting a puzzling phenomenon. Eur Respir J, 39, 669-676.

18. Fischer-Tenhagen C, Theby V, Kromker V, et al (2018): Detecting Staphylococcus aureus in milk from dairy cows using sniffer dogs. J Dairy Sci, 101, 4317-4324.

19. Friedrich RW, Laurent G (2001). Dynamic optimization of odor representations by slow temporal patterning of mitral cell activity. Science, 291, 889-894.

20. Grady SL, Purdy JG, Rabinowitz JD, et al (2013): Argininosuccinate synthetase 1 depletion produces a metabolic state conducive to herpes simplex virus 1 infection. Proc Natl Acad Sci US, 110, E5006-15.

21. Gisbert JP, Pajares JM (2004): 13C-urea breath test in the diagnosis of Helicobacter pylori infection-A critical. Aliment Pharm, 20, 1001-1017.

22. Grandjean D, Sarkis R, Tourtier JP, et al (2020): Detection dogs as a help in the detection of COVID-19 Can the dog alert on COVID-19 positive persons by sniffing axillary sweat samples? Proof-of-concept study. BioRxiv, 2020.06.03.132134.

23. Guest C, Pinder M, Doggett M, et al (2019): Trained dogs identify people with malaria parasites by their odour. Lancet Infect Dis, 19, 578-580.

24. Halpern M, Martinez, Marcos A (2003): Structure and function of the vomeronasal system: an update. Prog Neurobiol, 70, 245-318.

25. Horvath G, Järverud GAK, Järverud S, et al (2008): Human ovarian carcinomas detected by specific odor, Integr Cancer Ther, 7, 76-80.

26. Horvath G, Andersson H, Paulsson G (2010): Characteristic odour in the blood reveals ovarian carcinoma, BMC Cancer, 10, 643

27. Janik E, Ceremuga M, Niemcewicz M, et al (2020): Dangerous Pathogens as a Potential Problem for Public Health. Medicina, 56, 591.

28. Jendrny P, Schulz C, Twele F, et al (2020): Scent dog identification of samples from COVID-19 patients - a pilot study. BMC Infect Dis, 20, 536.

29. Jones RT, Guest C, Lindsay SW, et al (2020): Could biodetection dogs be used to limit the spread of COVID-19 by travellers? J Travel Med, 27, taaa131.

30. Koivusalo M, Vermeiren $\mathbf{C}$, Yuen J, et al (2017): Canine scent detection as a tool to distinguish meticillin-resistant Staphylococcus aureus. J Hosp Infect, 96, 93-96.

31. Kolk A, Hoelscher M, Maboko L, et al (2010): Electronicnose technology using sputum samples in diagnosis of patients with tuberculosis. Clin Microbiol, 48, 4235-8.

32. Leighton EA, Hare E, Thomas S, et al (2018): A solution for the shortage of detection dogs: a detection dog center of excellence and a cooperative breeding program. Front Vet Sci, 5, 284.
33. Lippi G, Heaney LM (2020): The "olfactory fingerprint": can diagnostics be improved by combining canine and digital noses? Clin Chem Lab Med, 58, 958-967.

34. Mashir A, Paschke KM, Van Duin D, et al (2011): Effect of the influenza A (H1N1) live attenuated intranasal vaccine on nitric oxide (FENO) and other volatiles in exhaled breath. J Breath Res, 5, 037107.

35. Maurer M, McCulloch M, Willey AM, et al (2016): Detection of bacteriuria by canine olfaction. Open Forum Infect Dis, 3, ofw051.

36. McCulloch M, Jezierski T, Broffman M, et al (2006): Diagnostic accuracy of canine scent detection in early-and late-stage lung and breast cancers. Integr Cancer Ther, 5, 30-39.

37. McGann JP (2017): Poor human olfaction is a 19thcentury myth. Science, 356, pii: eaam7263.

38. Meredith M (1998): Vomeronasal, olfactory, hormonal convergence in the brain. Cooperation or coincidence? Ann N Y Acad Sci, 30, 349-361.

39. Miekisch W, Schubert JK, Noeldge-Schomburg GFE (2004): Diagnostic potential of breath analysis-Focus on volatile organic compounds. Clin Chim Acta, 347, 25-39.

40. Pavlou AK, Magan N, Jones JM, et al (2004): Biosens Bioelectron. Detection of Mycobacterium tuberculosis (TB) in vitro and in situ using an electronic nose in combination with a neural network system. Biosens Bioelectron, 20, 538544.

41. Pavlova NN, Thompson CB (2016): The emerging hallmarks of cancer metabolism. Cell Metab, 23, 27-47.

42. Phillips M, Altorki N, Austin JHM, et al (2008): Detection of lung cancer using weighted digital analysis of breath biomarkers. Clin Chim Acta, 393, 76-84.

43. Pickel D, Manucy GP, Walker DB, et al (2004): Evidence for canine olfactory detection of melanoma. Appl Anim Behav Sci, 89, 107-116.

44. Quignon P, Kirkness E, Cadieu E, et al (2003): Comparison of the canine and human olfactory receptor gene repertoires, Genome Biology, 4, $\mathrm{R} 80$.

45. Remuzzi G (2020): COVID-19 and Italy: what next? Lancet, 395, 1225-1228.

46. Ritter JB, Wahl AS, Freund S, et al (2010): Metabolic effects of influenza virus infection in cultured animal cells: intra- and extracellular metabolite profiling. BMC Syst Biol, 4, 61.

47. Rosias PR, Dompeling E, Dentener MA, et al (2004): Childhood asthma: Exhaled markers of airway inflammation, asthma control score, and lung function tests. Pediatr Pulmonol, 38, 107-114.

48. Rothe C, Schunk M, Sothmann P, et al. (2020): Transmission of 2019- nCoV infection from an asymptomatic contact in Germany. N Engl J Med, 382, 970971.

49. Rouquier S, Giorgi D (2007): Olfactory receptor gene repertoires in mammals. Mutat Res-Fund Mol M, 616, $95-$ 102.

50. Schivo M, Aksenov AA, Linderholm AL, et al (2014): Volatile emanations from in vitro airway cells infected with human rhinovirus. J Breath Res, 8, 037110.

51. Schmidt K, Podmore IJ (2015): Current Challenges in Volatile Organic Compounds Analysis as Potential Biomarkers of Cancer. Biomark, 981458. 
52. Shirasu M, Touhara K (2011): The scent of disease: Volatile organic compounds of the human body related to disease and disorder. JBC, 150, 257-266.

53. Singhal TA (2020): Review of Coronavirus Disease-2019 (COVID-19). Indian J Pediatr, 87, 281-286.

54. Solga SF, Risby T (2010): What is Normal Breath? Challenge and Opportunity. IEEE Sens J, 10, 7-9.

55. Sonoda H, Kohnoe S, Yamazato T, et al (2011): Colorectal cancer screening with odour material by canine scent detection. Gut, 60, 814-819.

56. Špaňel P, Smith D (2011): Progress in SIFT-MS: Breath analysis and other applications. Mass Spec Rev, 30, 236267.

57. Taylor MT, McCready J, Broukhanski G, et al (2018): Using dog scent detection as a point-of-care tool to identify toxigenic Clostridium difficile in stool. Open Forum Infect Dis, 5, ofy179.

58. Teodoro-Morrison $\mathbf{T}$, Diamandis EP, Rifai $\mathbf{N}$, et al (2014): Animal olfactory detection of disease: promises and pitfalls. Clin Chem, 60, 1473-1479.

59. Thai M, Thaker SK, Feng J, et al (2015): MYC-induced reprogramming of glutamine catabolism supports optimal virus replication. Nat Commun, $6,8873$.

60. Thaker SK, Chapa T, Garcia G Jr, et al (2019): Differential Metabolic Reprogramming by Zika Virus Promotes Cell Death in Human versus Mosquito Cells. Cell Metab, 29, 1206-1216.e4.
61. Van den Velde S, Nevens F, Van Hee P, et al (2008): $G C$ $M S$ analysis of breath odor compounds in liver patients. Chromatogr B Analyt Technol Biomed Life Sci, 875, 3448.

62. Walker DB, Walker JC, Cavnar PJ, et al (2006): Naturalistic quantification of canine olfactory sensitivity. Appl Anim Behav Sci, 97, 241-254.

63. World Health Organization (1997): The World Health Report: Conquering suffering, enriching humanity. WHO Library Cataloguing-in-Publication Data. ISSN: 10203311.

64. World Health Organization (2007): The World Health Report: A safer future. Global public health security in the $21^{\text {st }}$ century. WHO Library Cataloguing-in-Publication Data. ISSN: 1020-3311.

65. Williams H, Pembroke A (1989): Sniffer dogs in the melanoma clinic? Lancet, 333, 734.

66. Willis CM, Church SM, Guest CM, et al (2004): Olfactory detection of human bladder cancer by dogs: Proof of principle study, Br Med J, 329, 712-714.

67. Xu F, Schaefer M, Kida I, et al (2005): Simultaneous activation of mouse main and accessory olfactory bulbs by odors or pheromones. J Comp Neurol, 489, 491-500.

68. Yu Y, Maguire TG, Alwine JC (2011): Human cytomegalovirus activates glucose transporter 4 expression to increase glucose uptake during infection. J Virol, 85, 1573-80. 